\title{
Watershed Prioritization Using Morphometric Analysis \& RUSLE Model for Soil Conservation Planning, in Gilgel Abay Watershed, Ethiopia
}



\section{Research}

Keywords: Morphometric analysis, RUSLE, soil erosion, Gilgel Abay watershed

Posted Date: December 15th, 2020

DOI: https://doi.org/10.21203/rs.3.rs-126047/v1

License: () (i) This work is licensed under a Creative Commons Attribution 4.0 International License. Read Full License 


\section{Abstract}

Background: Soil erosion is the predominant global land degradation process which leads to a decline in ecosystem services and functions. The Gilgel Abay watershed is one of the watersheds in Upper Blue Nile basin characterized by rapid population growth, deforestation, overgrazing, soil erosion, waterlogging and flooding. These contribute the land and water resources of the watershed and its ecosystem are under high risk. This study was aimed to prioritize high erosion risk areas of Gilgel Abay watershed for soil and water conservation planning using the Revised Universal Soil Loss Equation model and morphometric analysis. Using the Revised Universal Soil Loss Equation model, Sub watershed Prioritization was done by computing the annual soil loss rate by considering the five model parameters. The compound factor analysis technique was used for prioritize sub-watersheds through morphometric analysis.

Results: The result of estimated annual soil loss rates in Gilgel Abay watershed ranges from 0 to 781 tha-1 year ${ }^{-1}$, which is higher as compared to the limits of soil loss tolerance rates of the northern highlands of Ethiopia. From RUSLE model results, Sub watershed 4 was experiencing high erosion risks while, Subwatershed 2 followed by sub watershed 4 are high erosion risk areas of compound factor analysis.

Conclusion: The results of prioritization through both approaches show a quite alike output that is both identifies sub-watershed 4 and 2 as high erosion prone area. Therefore, both the results display a good efficiency in the assessment of erosion risks and giving priority in sub-watershed scale. Hence, the two approaches can be used to identify and delineate erosion-prone areas, and prioritize the areas for effective planning of sustainable land management options.

\section{Background}

Soil erosion is one of the biggest global environmental problems resulting in both on-site and off-site effects (Shiferaw, 2011). It is a global environmental problem that affects the productivity of all natural ecosystems and agriculture, which threaten the lives of most smallholder farmers (Gessesse et al., 2015a; Nigussie Haregeweyn et al., 2012; Keno \& Suryabhagavan, 2014). In the world water induced soil erosion takes the largest share of soil deterioration. It is reported that more than 2/3rd of farmland degradation in Africa is caused by soil erosion (Tully et al., 2015).

Soil erosion has accelerated in most parts of the world, especially in developing countries, due to different human induced factors and limited resources (BAYRAMiN et al., 2003). For instance, Reusing et al. (2000) highlighted that population growth, deforestation, intensive land cultivation, free grazing and higher demand for firewood often cause soil erosion. Soil erosion is generally more severe in tropical regions where rainfall is more intense and the soil is highly erodible due to the relatively shallow depth and low structural stability (Eaton, 1996).

Soil erosion has a far-reaching off-site impacts such as destruction of infrastructures, deposition of sediments and associated diversion of streams courses, and water quality decline (Balthazar et al., 2013; N. Haregeweyn et al., 2017; Tamene et al., 2011) Land degradations caused by soil erosion are the most popular problems in the highlands of Ethiopia, where a huge amount of fertile soil is being lost annually (Hurni, 1993). Soil erosion is one of the various factors affecting rural livelihoods, land productivity and sustainability, since it reduces the productive capacity of the land and exacerbates poverty and food insecurity (Adimassu et al., 2014; Angassa, 2014; Gessesse et al., 2015b; Lal, 2001).

Researches done in the highlands of Ethiopia (Amsalu \& De Graaff, 2007; Bewket \& Teferi, 2009; N. Haregeweyn et al., 2017; Hurni, 1993; Mengie Belayneh 2019) on the hazard of soil erosion revealed that, erosion-caused land degradations are by far the major problems, which remove soil's fertility, water holding capacity, and biodiversity. According to Hurni (1993), the soil loss by water erosion in Ethiopia accounts for 1,493 $\mathrm{Mg}_{\text {year }}^{-1}$, of this about $42 \mathrm{Mg} \mathrm{ha}^{-1}$ year $^{-1}$ is estimated for arable lands. This soil loss rate exceeds the tolerable soil loss rate of $18 \mathrm{Mg} \mathrm{ha}^{-1}$ year $^{-1}$ Hurni (1985b) and the soil formation rate of $3-7 \mathrm{Mg}$ $\mathrm{ha}^{-1}$ year $^{-1}$ Hurni (1983) estimated for Ethiopian highlands. As a result, more than $50 \%$ of the highlands of Ethiopia are already 'significantly eroded', $4 \%$ is beyond reclamation, and erosion causes a severe decline in land productivity at the rate of about $2.2 \%$ year ${ }^{-1}$ (FAO, 1986). Moreover, the accelerated erosion can reduce the per capita income and render highland cultivation unsustainable. Soil erosion has an estimated economic cost of around US\$ 1.0 billion year ${ }^{-1}$ by Sonneveld (2002), and between $2 \%$ and $3 \%$ of the national agricultural GDP by MoARD and World Bank (2007).

Monitoring soil erosion problem requires accurate estimation of soil loss rates and its spatial variation. In caring out any conservation programme, assessing the current status must be the first step (Hurni, 1985a). In this regard, quantitative assessment of soil erosion is a key to infer the extent and magnitude of the problem and identification of more vulnerable sites. Now a days, GIS and remote sensing based soil erosion estimation models are important for quantifying soil erosion rate and prioritization to initiate possible land management measures (Bewket \& Teferi, 2009; Khadse et al., 2015a; Markose \& Jayappa, 2016). There different model based methods (ranging from empirical to physically based models) which has been developed for soil erosion risk assessment and quantification (Zhang et al., 2009). The revised universal soil loss equation (RUSLE) Renard (1997) with its integration to geographic information system (GIS) techniques is among the most widely applied empirical models for assessment of sheet, inter-rill and rill erosion.

In a watershed management program due to time and financial limitation, it is difficult to make rehabilitation and conservation activities at one time in all places, thus it is important to study the watersheds of the area and make order by their risk of erosion (Tripathi et al., 2003). Morphometric analysis provides quantitative information about hydrogeologic, erosion prone areas and characteristics of watershed in terms of ground and surface water potential.Therefore, this study used the revised universal soil loss equation in which most of the parameters are calibrated in Ethiopian highland conditions Hurni (1985a), and morphometric analysis for erosion assessment and identification of erosion prone areas. In this regard, this study was aimed (1) to estimate potential soil loss rate in the study area (2) assess the magnitude of soil erosion hazard across sub-watersheds (3) to prioritize erosion hotspot areas and sub watersheds for conservation measures in the gigel abay watershed, northwestern highland of Ethiopia.

\section{Methodology}

\subsection{Description of the study area}


The study was done in Gilgel Abay watershed which is located in West Gojjam and Awi Administrative Zones of the Amhara National Regional State (ANRS) of Ethiopia. The watershed comprises a total of 10 Woredas and $3779.16 \mathrm{~km}^{2}$ estimated surface area. Geographically, the watershed lies between $10.95^{\circ}$ and $11.80^{\circ}$ latitudes and $36.70^{\circ}$ and $37.40^{\circ}$ longitudes (Fig. 1). The Gilgel Abay watershed falls within the cool sub humid zone with annual temperature of $17-$ $20^{\circ} \mathrm{c}$. The climate is generally temperate at higher elevations and tropical at lower elevations. The mean annual rainfall of the study area varies from around $1266 \mathrm{~mm}$ up to $2072 \mathrm{~mm}$. Rugged mountainous topography characterizes most part of the watershed especially in the southern part but there is some low land within the watershed. Elevation ranges from 1805 to $3534 \mathrm{~m}$ a s I. Around $80 \%$ of the watershed falls in the slope range of (0-6\%), $15 \%$ of the area falls in the slope range of (7-14\%) and the remaining $5 \%$ is steeper than $14 \%$ (Ashenafi, 2007).

\subsection{Data type and sources}

Both satellite and meteorological data measured from different stations of the watershed were used for the study. Two satellite images, i.e. Landsat 8 OLI and Surface Radar Topographic Mission (SRTM) digital elevation model products were freely acquired from https: https://earthexplorer.usgs.gov/ website. Landsat 8 OLI image were used for land use land cover classification and SRTM DEM were used for hydrological analysis (delineating watershed, subwatersheds, as well as generating slope and flow accumulation). GCPs were collected from handheld GPS for creating training areas for land use classification and accuracy assessment.

Daily rainfall data of eight stations (Merhawi, Bahirdar, Wotet Abay, Durbetie, Dangila, Sekela, Adet, Quarit) for ten years (2009-2018) were collected from the Ethiopian National Meteorological Agency. Mean annual rainfall data are generated from the daily rainfall data of 10 years and well adopted for the analysis. Soil data of the major soil groups were collected from Amhara Design and Supervision Work Enterprise.

Table 1 Description of data type and source

\begin{tabular}{|ll|}
\hline Data type & Data source \\
\hline Rainfall & Ethiopian Meteorological Agency \\
\hline Landsat 8 imagery & USGS/EROS (http://earth explorer.usgs.gov/) \\
\hline Soil map & Amhara Design Supervision Works Enterprise \\
\hline Digital Elevation Model (SRTM) & USGS/EROS (http://gdex. cr.usgs.gov/gdex/) \\
\hline Land management/conservation support & Google earth and existing literatures \\
\hline
\end{tabular}

\subsection{Satellite image processing}

Before the LULC classification, one should preprocess the distorted and degraded images to ensure the results of adequate quality with a more correct and faithful representation of the real ground scene. The Landsat 8 OLI image used for the study were preprocessed by using ERDAS imagine version 2015 software. The preprocessing activities including, atmospheric and radiometric correction to diminish the effects of clouds and the sun elevation angle of satellite images, band composition, and image enhancement operations like contrast adjustment, edge enhancement, and color composite were employed to enhance the interpretability of image data. Finally, the area of interest (Gilgel Abay watershed) was extracted using the subset tool available in ERDAS IMAGINE software.

\section{LULC Classification}

A computer-aided digital image classification procedure was used to classify satellite images to generate thematic LULC maps. The training signatures were collected for each LULC class from the field. A supervised classification method based on the Maximum Likelihood Classifier (MLC) algorithm was applied to classify the Landsat image. The watershed was classified into a total of seven major LULC classes. The thematic layer of the classified LULC images was validated using in-situ data and high resolution images like Google earth. Finally, classification accuracy was calculated using overall accuracy and Kappa Statistics.

\subsection{RUSLE model description}

There are a different models used to estimate soil erosion risk over many years worldwide (Farhan \& Nawaiseh, 2015; Lal, 2001). These models can be physical-based, empirical, and conceptual. The choice to apply these models depends on the availability of input data and the type of information needed. Even though there are number of soil erosion estimation models, RUSLE model is the most widely applied empirical model which was adopted in the present study. The RUSLE model is a practical tool for predicting the long-term average annual soil loss attributed to raindrop splash and runoff. It is an empirical prediction model easily applicable in different scales. To estimate annual mean soil erosion caused by rainfall, and identify the spatial pattern of the potential soil loss risks in the watershed, all RUSLE model erosion input factors are structured in raster format and co-register to a common pixel resolution and datum (Renard KG, 1997).

\section{A = R. K. L. S. C.P - (Eq. 1)}

where $\mathbf{A}=$ average annual soil loss per unit of area (ton $\mathrm{ha}^{-1}$ year ${ }^{-1}$ ); $\mathbf{R}=$ the rainfall erosivity factor [MJ $\mathrm{mm}$, $\left(\mathrm{ha}^{-1}\right.$ year $^{-1}$ )]; derived from daily precipitation data; $\mathrm{K}=$ the soil erodibility factor [ton ha-1 $\mathrm{h} \mathrm{MJ}^{-1} \mathrm{ha}^{-1} \mathrm{~mm}^{-1}$ )]; derived from information on soil types; LS = topographic factor, i.e., length of the slope and percent of the slope steepness (dimensionless), respectively; derived from a DEM; C = the land cover and management factor (dimensionless); derived from 
LULC classification of satellite image data; and $\mathbf{P}=$ the conservation support factor, which accounts for soil erosion control measures (dimensionless) derived from field observation and literature.

Once the RUSLE model is run, classification of soil erosion risk area was based on the estimated rate of mean annual soil loss. Thus the erosion risk area was categorized into eight classes from very low to extremely high (Uddin et al., 2016) (Table 2).

Table 2

Standards for the soil erosion risk classification

\begin{tabular}{|ll|}
\hline Erosion risk class & Rate of erosion $\left(\mathrm{t} \mathrm{ha}^{-1}\right.$ year $\left.^{-1}\right)$ \\
\hline Very low & $<5$ \\
\hline Low & $5-10$ \\
\hline Low medium & $10-15$ \\
\hline Medium & $15-20$ \\
\hline High medium & $20-25$ \\
\hline High & $25-35$ \\
\hline Very High & $35-50$ \\
\hline Extremely High & $>50$ \\
\hline
\end{tabular}

\section{Rainfall Erosivity Factor (R)}

Rainfall erosivity is a climatic factor, which is estimated from the rainfall data. It is a measure of the kinetic energy $\left(E, M J \mathrm{~m}^{2}\right)$ based on the 30 min maximum intensity of rainfall (I30, mm h-1) (Wischmeier \& Smith, 1978). For this study, an empirical equation developed by (Kaltenrieder, 2007) (Eq. 2) were used to estimate local erosivity values from the available total annual rainfalls. The value of R in Gilgel Abbay ranges from 558 to 736 (Fig. 2).

$R=0.36 X+47.6$

Where, $\mathbf{X}$ is mean annual rainfall in $\mathrm{mm}$ and $\mathbf{R}$ is rainfall erosivity factor.

\section{Soil Erodibility Factor (K)}

The soil erodiblity ( $\mathrm{K}$ factor) indicates soil's susceptibility to detachment and transport by agents of erosion. $\mathrm{K}$ factor values were determined from the available soil data. We used the monograph method (Eq. 3) developed by (Wischmeier et al., 1971) to calculate the $k$ factor. The $k$ value ranges from 0.0595 to 0.234 (Fig. 3).

$K=(1.292)\left[2.1 * 10^{-6} \mathrm{fp}^{1.14}\left(12-\mathrm{P}_{\mathrm{om}}\right)+0.0325\left(\mathrm{~S} \mathrm{~s}_{\text {tru }}-2\right)+0.025\left(\mathrm{f}_{\text {perm }}-3\right)\right]-$ (Eq. 3)

Where, $\mathrm{fp}$ is the particle size parameter (unitless), Pom is the percent organic matter (unitless), Sstruc is the soil structure index (unitless), fperm is the profilepermeability class factor (unitless), Psilt is the percent silt (unitless) and Pclay is the percent clay (unitless).

\section{Topographic Factors (LS)}

Slope length (L) and slope steepness (S) factors were computed from a $30 \mathrm{~m}$ resolution Digital Elevation Model (DEM) of the watershed using the formula indicated in (Eq. 4).

\section{LS $=(\text { flow accumulation * cell value } / 22.1)^{\mathrm{m}}\left(0.065+0.045 \mathrm{~S}+0.0065 \mathrm{~S}^{2}\right)-$-(Eq. 4)}

Where, LS is slope steepness-length factor, the cell value is the resolution of DEM which is $30 * 30 \mathrm{~m}$ and $\mathrm{S}$ is slope in percent generated from DEM. The value of $\mathbf{m}$ ranges from $0.2-0.5$ depending on the slope (Wischmeier \& Smith, 1978). The $L$ and $\mathbf{S}$ factors were computed independently and the value ranges from 0-36 (Fig. 4) for slope length and 0.075 to 14.64 for slope steepness respectively (Fig. 5)

\begin{tabular}{|ll|}
\multicolumn{1}{c}{$\begin{array}{c}\text { Table 3 } \\
\text { m value }\end{array}$} \\
\begin{tabular}{|ll|}
\hline m-value & Slope (\%) \\
\hline 0.5 & $>5$ \\
0.4 & $3-5$ \\
\hline 0.3 & $1-3$ \\
\hline 0.2 & $<1$ \\
\hline
\end{tabular}
\end{tabular}

\section{Cover Management Factor (C)}

The cover management factor $(C)$ represents the effects of vegetation, management and erosion control practices on soil loss rates. The value ranges from 1.0 in completely bare land (no cover) to 0.0 in water body or completely covered land surface. Land use/ cover classification map and normalized difference 
vegetation index (NDVI) are the most commonly used methods for C-value estimation. In this study, we selected land use/cover classification map approach since it gives comparatively precise C-value than normalized difference vegetation index (NDVI) (Lin D, 2017) and the value ranges from 0.0196 to 0.25 (Fig. 6).

Table 4

C factor values derived from land cover classes

\begin{tabular}{|llll|}
\hline Major land use & Subunits & C factor & References \\
\hline Built-up area & Town & 0 & (Moges \& Bhat, 2017) \\
\hline Natural forest & Dense natural forest & 0.01 & (Hurni, 1985b) \\
\hline shrub land & Dense shrubland & 0.02 & Krishna (2009) \\
\hline Built-up area & Farm village & 0.05 & (Moges \& Bhat, 2017) \\
\hline cultivated land & Intensively cultivated land & 0.25 & (Hurni, 1985b) \\
\hline cultivated land & Moderately cultivated land & 0.15 & (Brhane \& Mekonen, 2009; Hurni, 1985b) \\
\hline grassland & Open grassland & 0.05 & (Hurni, 1985b) \\
\hline shrub land & Open shrubland & 0.06 & (Eweg HPA, 1996) \\
\hline plantation forest & Plantation forest & 0.01 & (Hurni, 1985b) \\
\hline Waterbody & Rivers & 0 & Ongsomwang and Thinley \\
& & & (2009) \\
\hline grassland & Shrub grassland & 0.01 & (Eweg HPA, 1996) \\
\hline cultivated land & Sparsely cultivated land & 0.06 & (Hurni, 1985b), (TEFERI, 2009) \\
\hline
\end{tabular}

\section{Conservation practice $(P)$ factor}

The conservation practice factor ( $P$ factor) refers to the effects of land conservation practices in minimizing the quantity and rate of rainfall-runoff and soil erosion (Wischmeier \& Smith, 1978). The conservation practice factor signifies the ratio of soil erosion from land treated with a specific conservation measure to its equivalent soil loss from up and downslope tillage. P-value can be determined by the type of conservation measure implemented. This study was employed an alternative method using a combination of slope and land use/covers for estimation of the P-value (Fig. 7) as proposed by (Wischmeier \& Smith, 1978) in (Table 5).

Table 5

Land management factor $(P)$ values suggested by Wischmeier and Smith (1978)

\begin{tabular}{|llll|}
\hline Land-use type & Slope & $\mathbf{P}$ factor & References \\
\hline Agricultural land & $0-5$ & 0.1 & \\
\cline { 2 - 4 } & $5-10$ & 0.12 & \\
& $10-20$ & 0.14 & (Wischmeier \& Smith, 1978) \\
\hline & $20-30$ & 0.19 & \\
& $30-50$ & 0.25 \\
\hline Other Land & All & 1.00 \\
\hline
\end{tabular}

\subsection{Morphometric analysis}

A number of morphometric parameters which signify the watershed characteristics were computed in ArcGIS 10.5 environment. In this study, the main watershed was discretized into four sub-watersheds using Arc SWAT extension. Surface Radar Topographic Mission (SRTM) digital elevation model of $30 \mathrm{~m}$ * $30 \mathrm{~m}$ was used for watershed delineation and characterization. The formulas indicated in Table (6) were used to compute the individual morphometric parameters. Both linear and shape morphometric parameters such as; Stream Order (u), Stream Number (Nu), Stream Length (Lu), Mean Stream Length (Lsm), Drainage Texture (Dt), Bifurcation Ratio (Rb), Drainage Density (Dd) and Stream Frequency (Fs) Form factor (Ff), Circulatory ratio (Rc), Elongation ratio (Re) and compactness coefficient (Cc) were used for watershed prioritization. 
Table 6

Morphometric attributes and formula/method used for computation for the sub-watersheds of Gilgel abay watershed

\begin{tabular}{|c|c|c|c|}
\hline Category of parameter & Morphometric parameters & Equation & Reference \\
\hline \multirow[t]{7}{*}{ Linear parameters } & Stream order $(\mathrm{u})$ & Hierarchical Rank & Strahler (1964) \\
\hline & Stream number $(\mathrm{Nn})$ & $\mathrm{Nu}=\mathrm{N} 1+\mathrm{N} 2+\ldots .+\mathrm{Nn}$ & Horton (1945) \\
\hline & Stream length (Lt km) & $\mathrm{Lt}=\mathrm{L} 1+\mathrm{L} 2+\ldots . . \mathrm{Ln}$ & Strahler (1964) \\
\hline & Mean stream length (RI) & $\mathrm{Lum}=\mathrm{Lu} / \mathrm{Nu}$ & Strahler (1964) \\
\hline & Bifurcation ratio $(\mathrm{Rb})$ & $\mathrm{Rb}=\mathrm{Nu}+1 / \mathrm{Nu}$ & Strahler (1964) \\
\hline & Mean bifurcation ratio (Rbm) & $\mathrm{Rbm}=$ Average Of bifurcation & Strahler (1964) \\
\hline & Basin length (Lb) & $\mathrm{Lb}=1.321 \times \mathrm{A}^{0.568 \mathrm{a}}$ & Nooka (2005) \\
\hline \multirow[t]{8}{*}{ Shape parameters } & Drainage texture & $\mathrm{Dt}=\mathrm{Lu} / \mathrm{P}$ & Horton (1932) \\
\hline & Drainage density & $\mathrm{Dd}=\mathrm{Lu} / \mathrm{A}$ & Horton (1932) \\
\hline & Stream frequency & $\mathrm{Fs}=\mathrm{Nu} / \mathrm{A}$ & Horton (1932) \\
\hline & Infiltration number (If) & If $=F s^{\star} D d$ & Faniran (1968) \\
\hline & Elongation ratio & $\mathrm{Re}=(2 / \mathrm{Lb}) \star 2 \sqrt{ }(\mathrm{A} / \pi)$ & (Schumm, 1956) \\
\hline & Circularity ratio & $\mathrm{Rc}=4 \pi^{\star} A / p^{2}$ & Miller (1953) \\
\hline & Form factor & $F f=A / L b^{2}$ & Horton (1932) \\
\hline & Compactness coefficient & $C c=0.2821\left(P / A^{0.5}\right)$ & (Gravelius, 1914) \\
\hline
\end{tabular}

\subsection{Sub watershed Prioritization using RUSLE}

Identifying areas that are highly vulnerable to soil loss is a critical factor for designing and implementing appropriate conservation measures. Prioritization was done at sub-watershed scales considering areas with a higher soil loss and increases in erosion risk. Using RUSLE model prioritization was done by calculating the amounts of soil loss for each sub-watershed by using the Zonal Statistics tool of Spatial Analyst extension in ArcGIS 10.5 software. Finally, prioritization of sub-watersheds for soil and water conservation activity was done based on the magnitude of soil loss in each sub-watershed and subwatersheds experiencing high mean annual soil loss rate are first prioritized for soil conservation planning.

\subsection{Sub watershed Prioritization using compound factor (CF) model}

Compound factor model is a very précised method to evaluate the earth surface properties particularly for the basin scale in various works of literature and comprehensively used for sustainable water resource management and scientific planning of sub-watersheds in data scarce areas (Altaf et al., 2013). In this approach, we used the results of linear, areal or shape parameters of morphometric results for prioritization of sub-watersheds. It has been reported that linear parameters have a direct relationship with erodibility. Thus, parameters (stream length, mean stream length, bifurcation ratio, and length of overland flow) was rated as rank 1, second highest value was rated as rank 2 and so on, and the least value was rated last in rank (Biswas. et al., 1999; Ratnam et al., 2005). By contrast, the shape parameters have an inverse relation with linear parameters, so that the lower their value, the greater the erodibility (Patel \& Dholakia, 2010; Patel et al., 2012). Therefore, the lowest value of shape parameters (elongation ratio, compactness factor, circularity ratio, form factor) was rated as rank 1 , the next lower value was rated as rank 2 and so on and the highest value was rated last in rank. Then Compound factor is computed by summing all the values of linear parameters as well as shape parameters and then dividing by number of parameters. The subwatershed with the lowest rank was given higher priority according to (Vandam, 2013). Subwatersheds with the highest $\mathrm{Cp}$ values have low priority while those with the lowest $\mathrm{Cp}$ values have been high priority.

\section{Results And Discussion}

\subsection{Soil Erosion Risk in the Gilgel Abay Watershed}

A quantitative expression of soil erosion rate is a fundamental phase for any soil and water management practices (Khadse et al., 2015b; Prasannakumar et al., 2012). The study tried to quantify and map soil erosion rates in Gilgel Abay watershed. The soil erosion risk map is shown in (Fig. 9), while the statistical details of the soil loss rates are presented in (Table 7). The estimated annual soil loss rates in Gilgel Abay watershed ranges from 0 to $781 \mathrm{t} \mathrm{ha}^{-1} \mathrm{year}^{-1}$. If we compared the estimated soil loss rate to the limits of soil loss tolerance suggested by Rose (1994) (10 $\mathrm{t} \mathrm{ha}^{-1}$ year $^{-1}$ for tropical region) and Hurni (1986) 2-18 $\mathrm{t} \mathrm{ha}^{-1}$ year $^{-1}$ for the various agro-ecological belts of Ethiopia and $10 \mathrm{tha}^{-1} \mathrm{year}^{-1}$ to the northern highlands of Ethiopia, it is higher. When we compare this result with the predicted annual soil loss rate in Lake Tana basin which is $>60 \mathrm{tha}^{-1}$ year $^{-1}$ in rugged topographies and it decreases up to $15 \mathrm{t} \mathrm{ha}^{-1} \mathrm{year}^{-1}$ in the area with better catchments characteristics (Birru, 2007). Gilgel Abay watershed becomes one of the watersheds that contribute a large amount of soil loss in Lake Tana basin.

\subsubsection{Soil erosion rate in sub watersheds}

Page 6/21 
The extent and magnitude of soil loss rate varies from one part of the country to another, one watershed to the other depending on the farming practices, population pressure, type and susceptibility of the soils to erosion, local climate, the general terrain configurations, and variations in agro ecological setting of the area (Monsieurs et al., 2015; Tebebu et al., 2010). In this study the magnitude and extent of soil loss varies across sub watersheds. The statistical result of the study reveals that, the mean soil loss rate is relatively higher in sub watershed4, which is found in the south east direction of the watershed. From the field observation, this sub watershed is characterized by rugged topography and gains relatively high rain fall. The least erosion rate is recorded in sub watershed1 which is found in the Northern part of the Gilgel Abbay watershed which is flat in topography.

Table 7

potential soil erosion in sub watersheds

\begin{tabular}{|llll|}
\hline Sub watersheds & Mean & Priority rank & Area $\left(\mathbf{m}^{2}\right)$ \\
\hline Sub watershed 4 & 7.826189492 & 1 & 443431250 \\
\hline Sub watershed3 & 6.07473607 & 2 & 605327149.5 \\
\hline Sub watershed2 & 3.015195833 & 3 & 418368817.6 \\
\hline Sub watershed1 & 1.586530646 & 4 & 154524874 \\
\hline
\end{tabular}

\subsubsection{Prioritization of sub-watersheds based on RUSLE}

In a watershed management program due to time and financial limitation, it is difficult to make rehabilitation and soil and water conservation activities at one time in all places, thus it is important to study the watersheds of the area and make ordering by their risk of erosion (Tripathi et al., 2003). Proper identification of areas that are highly vulnerable to soil loss is a critical factor for designing and implementing appropriate SWC measures. In this study, prioritization was done at sub-watershed scales based on the magnitude of soil erosion rates in the sub-watersheds. Among the 4 sub-watersheds, Sub-watershed 4 which is found in the southeast direction of the watershed has relatively high erosion rates followed by sub watershed3 as indicated in (Table 7) and (Fig. 11). This sub-watershed also consists of the maximum erosion rate of the watershed. As a result, the priority for soil conservation activity is given for sub-watershed 4 followed by sub-watershed 3 .

\subsection{Morphometric analysis}

The morphometric analysis results of linear and areal parameters of the 4 sub-watersheds are computed by using different formulas (Table 6 ) and presented in table (8 and 9).

\subsubsection{Linear parameters}

Linear aspects of the watershed are one-dimensional characteristic of morphometric analysis which closely linked with the channel patterns of the drainage network. This study accounted linear parameters like: Stream Order, bifurcation ratio, stream length, mean stream length, drainage texture, stream frequency, infiltration number.

\section{Stream order (u)}

Stream ordering is a widely applied method for stream classification in a river basin. It is a measure of the position of a stream in the hierarchy of tributaries (Leopold et al. 1964) and the streams of sub watersheds in Gilgel abay watershed have been demarcated according to the Strahler's system of stream ordering. The first order stream has no tributary, and its flow depends totally on the surface overland flow to it. Similarly, the second-order stream is formed by the junction of the two first-order streams and thus, has a higher surface flow and the third-order streams receive flow from two second-order stream (Patel et al., 2012). In the present study, sub watershed 1 and 4 are of third-order, and sub watershed 2 and 3 are fourth level stream orders.

\section{Stream number $(\mathrm{Nu})$}

Stream number is the number of the stream segments of any particular order in a sub watershed. The values were computed using Horton's law. The orderwise stream numbers and stream length of gigel abay watershed are given in (Table 8). Streams with relatively short lengths represent the areas having finer texture with steep slopes, whereas longer lengths of stream are generally indicative of gentle slopes (Strahler, 1964).

\section{Bifurcation ratio $(\mathrm{Rb})$}

Bifurcation ratio is the ratio of the number of stream segments of given order to the number of segments of next higher order (Horton, 1945). It is a dimensionless property and shows the degree of integration prevailing between streams of various orders in a drainage basin. Bifurcation ratio is an index of relief and topographic dissection and its value varies between 2 for flat or rolling catchments, and 6 for watersheds distorted remarkably by geological structure. Table 8 shows a prominent variation in the bifurcation ratio $(\mathrm{Rb})$ of gigel abay sub watersheds. The value of bifurcation ratio was in between 2 and 3.6.

\section{Drainage density (Dd)}

Drainage density is a measure of the closeness of spacing of channels. It reveals how well or how poorly a watershed is drained by stream channels. The measurement of Dd is a useful numerical measure of landscape analysis and runoff potential. Drainage density is affected by the initial relief, soil infiltration, and underlying rock type. A high drainage density value indicates a relatively high density of streams, high runoff, a quick stream response, and consequently 
a low infiltration rate, while a low drainage density means a poorly drained basin with a slow hydrologic response (Prasad et al., 2008). The Dd value in the study ranges from 0.346 to $0.42 \mathrm{~km} / \mathrm{km}^{2}$ (Table 8) which shows sub watersheds are less dissected and experiencing poor drainage.

\section{Drainage texture $(\mathrm{Dt})$}

Drainage texture is the total stream number of all orders per perimeter of that area (Horton, 1945). The drainage texture depends upon vegetation, climate, rock and soil type, infiltration capacity, relief and stage of development (Ameri et al., 2018). The drainage texture can be classified into five classes such as very coarse $(<2)$, coarse $(2-4)$, moderate $(4-6)$, fine $(6-8)$, very fine $(>8)$. In the study area, all the sub watersheds have value below 2 which falls under the class very coarse drainage texture.

\section{Stream frequency (Fs)}

As Horton (1932) defined stream frequency (Fs) or channel frequency is the total number of stream segments of all order per unit area. It depends upon the lithology of the basin and the texture of the drainage network. It has a positive relation with the drainage density because of the increase in stream population is connected to that of drainage density. High stream frequency means more percolation with respect to drainage density, and thus, more groundwater potential (Sreedevi et al., 2013). The value of drainage frequency ranges from 0.0662 to 0.0934 streams $/ \mathrm{km}^{2}$ (Table 8 ).

\section{Infiltration number (If)}

It is the product of drainage density and stream frequency. It gives us an idea about the infiltration characteristics of the watershed. Infiltration number is inversely proportional to the infiltration capacity of the basin. Higher infiltration number means lower infiltration and higher runoff. A greater value of 'If' reveals impermeable surface and resistance to soil loss, in the contrary lower values point towards erosive nature of the watersheds. In the present study, sub watershed 3 and 4 has the lowest 'If' value with higher risk for erosion, and sub watershed 2 has the highest value with an indicator of resistance to erosion (Table 8).

\subsubsection{Shape parameters}

The shape of a watershed is controlled by geological structure, lithology, relief and climate, and varies from narrow elongated forms to circular or semi-circular forms. The shape mainly governs the rate at which water is supplied to the main channel. In the present study, different parameters, such as: Form factor (Ff), elongation ratio $(\mathrm{Re})$, circularity ratio $(\mathrm{Rc})$, and compactness coefficient $(\mathrm{Cc})$ were used for characterizing watershed shape, which is an important parameter from hydrological perspective.

\section{Elongation Ratio (Re)}

Elongation ratio is the ratio of diameter of a circle having the same area as of the basin and maximum basin length (Schumm, 1956). It is a very significant index in the analysis of basin shape which helps to give an idea about the hydrological character of a drainage basin. The lowest value of elongation ratio indicates that high relief and steep slope, while very high values indicates the plain land with low relief and low slope. The value of the elongated ratio can be classified in to circular $(>0.9)$, oval $(0.9-0.8)$ and elongated $(<0.7)$. A circular basin is more efficient in runoff discharge than an elongated basin (Singh \& Singh, 1997). In this study, the majority of the area has high relief and steep sloped. The value of the elongated ratio I the present study ranges from 0.55 to 0.61 (Table 9) which reveals the sub watersheds are slightly elongated. These brought sub watersheds for high susceptibility to erosion resulted from generation and transportation of high amount of sediment load.

\section{Circularity ratio $(\mathrm{Rc})$}

The circulatory ratio is a quantitative expression of the shape of basin, which is expressed as the ratio of basin area to the area of circle, having the same perimeter as the basin. According to miller (1953), the values of Rc is influenced by the stream length and frequency, geology, relief, land use and land cover and climatic condition of the basin. If the value of Rc is exactly 1 the basin is set to be a perfectly circular shape, while less than 1 indicates that the watershed is elongated in shape. Analysis results indicates the sub watersheds have a circularity ratio of in between 0.17 and 0.23 (Table 9) which indicates the geologic strata of the sub watersheds are composed of relatively homogeneous and highly permeable geologic materials. In addition, slightly elongated sub watersheds experience slow runoff discharge due to runoff from various parts of the sub watershed not reaching the outlet at the same time and highly permeable subsoil.

\section{Form factor (Ff)}

Form factor is a ratio of watershed area to the square of the length of the watershed (Horton, 1932). The value of form factor would always be greater than 0.78 for perfectly circular basin (Strahler, 1964). Short duration high peak flows are common for the sub watershed with high form factors (circular), whereas elongated sub watersheds with low form factor indicate flow for longer duration (Chopra et al., 2005). In the present study, the Ff was in between 0.24 and 0.29 indicating no sudden peak discharge at the outlet in the sub watersheds.

\section{Compactness coefficient (Cc)}

According to Gravelius (1914), compactness coefficient also known as the Gravelius index (GI) is the ratio of perimeter of watershed to circumference of circular area, which equals the area of the watershed. It is independent of the size of watershed and dependent only on the slope (Horton, 1945). It is the deviation of shape of the watershed from a circular watershed. Compactness Coefficient (Cc) is used to express the relationship of a hydrological basin with that of a circular basin having the same area as the hydrologic basin. Cc > 1.0 indicates more deviation from the circular nature (Altaf et al., 2013). Lower values of this parameter denote more elongation of the basin and less erosion, while higher values indicate less elongation and high erosion. The Cc value for the study ranges from 2 to 2.4 (Table 9). 
Table 8

linear parameters of Gilgel Abay watershed

\begin{tabular}{|c|c|c|c|c|c|c|c|c|c|c|c|}
\hline \multirow{2}{*}{$\begin{array}{l}\text { Name of } \\
\text { sub } \\
\text { watershed }\end{array}$} & & & & & & & & & & & \\
\hline & $\begin{array}{l}\text { Stream } \\
\text { order }\end{array}$ & $\begin{array}{l}\text { No of } \\
\text { stream } \\
\text { segment }\end{array}$ & $\begin{array}{l}\text { Stream } \\
\text { length(KM) }\end{array}$ & $\begin{array}{l}\text { Mean } \\
\text { stream } \\
\text { length(KM) }\end{array}$ & $\begin{array}{l}\text { Bifurcation } \\
\text { ratio }\end{array}$ & $\begin{array}{l}\text { Mean } \\
\text { bifurcation } \\
\text { ratio }\end{array}$ & Area $(\mathrm{km} 2)$ & Perimeter & $\mathrm{Dd}$ & $\mathrm{Dt}$ & $\mathrm{fl}$ \\
\hline \multirow{3}{*}{$\begin{array}{l}\text { Sub } \\
\text { watershed1 }\end{array}$} & I & 9 & 62.641 & 4.81 & & 2 & 156.32 & 99.6 & 0.400734 & 0.130522 & 0.03332 \\
\hline & II & 3 & & & 3 & & & & & & \\
\hline & III & 1 & & & 3 & & & & & & \\
\hline \multirow{4}{*}{$\begin{array}{l}\text { Sub } \\
\text { watershed2 }\end{array}$} & I & 30 & 180.17 & 4.504 & & 2.5 & 428.2 & 177.32 & 0.420761 & 0.225581 & 0.03930 \\
\hline & II & 6 & & & 5 & & & & & & \\
\hline & III & 3 & & & 2 & & & & & & \\
\hline & IV & 1 & & & 3 & & & & & & \\
\hline \multirow{4}{*}{$\begin{array}{l}\text { Sub } \\
\text { watershed3 }\end{array}$} & 1 & 30 & 244.67 & 5.95 & & 2.41 & 619.06 & 182.2 & 0.395231 & 0.225027 & 0.02617 \\
\hline & II & 7 & & & 4.29 & & & & & & \\
\hline & III & 3 & & & 2.34 & & & & & & \\
\hline & IV & 1 & & & 3 & & & & & & \\
\hline \multirow{3}{*}{$\begin{array}{l}\text { Sub } \\
\text { watershed4 }\end{array}$} & I & 29 & 156.12 & 3.63 & & 3.61 & 451.1 & 162.89 & 0.346087 & 0.221008 & 0.02761 \\
\hline & ॥ & 6 & & & 4.84 & & & & & & \\
\hline & III & 1 & & & 6 & & & & & & \\
\hline
\end{tabular}

Table 9

shape morphometric parameters of Gilgel Abay watershed

\begin{tabular}{|c|c|c|c|c|c|}
\hline \multicolumn{6}{|c|}{ shape parameters } \\
\hline ID & Sub-watershed & Elongation ratio(Re) & Circularity ratio(Rc) & Compactness coefficient(Cc) & Form factor (Ff) \\
\hline 1 & S1 & 0.61 & 0.1979 & 2.247413 & 0.29223 \\
\hline 3 & $\mathrm{~S} 2$ & 0.5697 & 0.171 & 2.417455 & 0.2543 \\
\hline 3 & S3 & 0.5556 & 0.234 & 2.065861 & 0.253069 \\
\hline 4 & S4 & 0.568 & 0.21353 & 2.163533 & 0.242358 \\
\hline
\end{tabular}

\subsubsection{Prioritization of sub-watersheds using morphometric analysis}

Morphometric analysis is a significant tool for the prioritization of sub-watersheds even without considering the soil parameters (Biswas. et al., 1999). Though By prioritization of watersheds, one can conclude which watershed can lead higher amount of discharge due to excessive amounts of rainfall. In this study, Sub watersheds are prioritized for soil and water conservation planning based on morphometric analysis of the linear and shape parameters. Computing compounding factor is the technique used to prioritize sub-watersheds as indicated in (Table 10). The compound factor was computed by summing all the values of linear parameters as well as shape parameters and then dividing by the number of parameters. The sub-watershed with the lowest rank was given higher priority according to (Vandam, 2013). The Results of the analysis showed that sub-watershed2 $(\mathrm{cp}=1.8)$ followed by sub watershed4 $(\mathrm{cp}=2.3)$ were high erosion risk areas \& prior soil control measures are required in these sub-watersheds to preserve the area from further erosion. The compounding factor value for Sub watershed 1 is the least among the four sub-watersheds and gets the least rank.

Table 10

Calculation of compound factor and prioritized ranks for the sub watersheds.

\begin{tabular}{|c|c|c|c|c|c|c|c|c|c|c|c|}
\hline $\begin{array}{l}\text { sub } \\
\text { watershed }\end{array}$ & $\begin{array}{l}\text { Stream } \\
\text { order } \\
(\mathrm{Rb})\end{array}$ & $\begin{array}{l}\text { Drainage } \\
\text { Density } \\
\text { (Dd) }\end{array}$ & $\begin{array}{l}\text { Drainage } \\
\text { Texture } \\
\text { (Dt) }\end{array}$ & $\begin{array}{l}\text { Stream } \\
\text { ferquency(Sf) }\end{array}$ & $\begin{array}{l}\text { Infiltration } \\
\text { Number(If) }\end{array}$ & $\begin{array}{l}\text { Elongation } \\
\text { ratio } \\
(\mathrm{Re})\end{array}$ & $\begin{array}{l}\text { circularity } \\
\text { ratio(Rc) }\end{array}$ & $\begin{array}{l}\text { Compactness } \\
\text { coeff(Cc) }\end{array}$ & $\begin{array}{l}\begin{array}{l}\text { Form } \\
\text { factor }\end{array} \\
\text { (Ff) }\end{array}$ & $\begin{array}{l}\text { compound } \\
\text { factor(Cp) }\end{array}$ & $\begin{array}{l}\text { prioritiz } \\
\text { ranks }\end{array}$ \\
\hline S1 & 4 & 2 & 4 & 2 & 2 & 4 & 2 & 3 & 4 & 3 & 4 \\
\hline s2 & 2 & 1 & 1 & 1 & 1 & 3 & 1 & 4 & 3 & 1.888889 & 1 \\
\hline s3 & 3 & 3 & 2 & 4 & 3 & 1 & 4 & 1 & 2 & 2.555556 & 3 \\
\hline s4 & 1 & 4 & 3 & 3 & 2 & 2 & 3 & 2 & 1 & 2.333333 & 2 \\
\hline
\end{tabular}

\section{Conclusion}


This study was aimed to identify the most erosion vulnerable sub-watersheds for soil erosion in Gilgel Abay watershed. The empirical erosion assessment model and morphometric analysis of the linear and shape parameters were used. The two techniques use different datasets and follow different approaches to prioritize high erosion risk areas or sub-watersheds. The RUSLE potential soil loss estimation model gives a good implication of soil erosion intensity and variability in Gilgel Abay watershed. Among the four sub-watersheds in Gilgel Abay, sub watershed4 was experiencing relatively high mean soil loss and the first priority was given to this watershed due to a relatively high magnitude of soil erosion followed by sub watershed 3 . Sub watershed 1 was the least prioritized sub-watershed because of relatively less intensity of soil erosion.

The morphometric analysis of the watershed gives the potential high erosion risk areas in the watershed by considering the linear and shape aspects instead of quantifying the amount of erosion loss in each cell. The compounding factor value of sub watershed 2 is low as compared to the other sub-watersheds and it was first prioritized for soil and conservation planning and followed by sub watershed 4 .

The present study demonstrated the effectiveness of RUSLE and compound factor-based prioritization methods with the assist of GIS techniques. Both approaches can be used to identify and delineate erosion-prone areas, and prioritize the areas for effective planning of sustainable land management based on erosion severity levels in the watersheds.

\section{Declarations}

\section{Ethics approval and consent to participate}

An attempt was made to conduct the research in an ethical manner. Hence, as the researcher, the Authors take full responsibility for all the contents and any mistakes here in the document.

\section{Consent for publication}

We all have agreed to submit our final manuscript for Environmental Systems Research journal and approved the submission.

\section{Availability of data and materials}

The datasets used and/or analyzed during the current study are available from the corresponding author on reasonable request.

\section{Competing interests}

The authors declare that they have no competing interests.

\section{Funding}

No funding was received.

\section{Authors' contributions}

The corresponding author has led the overall research process starting from the design to data analysis and interpretation of results. Both the co-authors have been involved by providing critical comments and suggestions during the research process and manuscript write up. All the authors have read and approved the final manuscript.

\section{Acknowledgements}

None

\section{Authors' information}

Not applicable

\section{References}

1. Adimassu, Z., Mekonnen, K., \& Yirga, C. (2014). Effect of soil bunds on runoff, soil and nutrient losses, and crop yield in the central highlands of Ethiopia. Journal of Land Degradation Development, 25(6), 554-564.

2. Altaf, F., Meraj, G., \& Romshoo, S. A. (2013). Morphometric analysis to infer hydrological behaviour of Lidder watershed, Western Himalaya, India. Geography, 2013.

3. Ameri, A. A., Pourghasemi, H. R., \& Cerda, A. (2018). Erodibility prioritization of sub-watersheds using morphometric parameters analysis and its mapping: A comparison among TOPSIS, VIKOR, SAW, and CF multi-criteria decision making models. Science of the Total Environment, 613, 1385-1400.

4. Amsalu, A., \& De Graaff, J. J. E. e. (2007). Determinants of adoption and continued use of stone terraces for soil and water conservation in an Ethiopian highland watershed. 61(2-3), 294-302.

5. Angassa, A. (2014). Effects of grazing intensity and bush encroachment on herbaceous species and rangeland condition in southern Ethiopia. Journal of Land Degradation Development, 25(5), 438-451. 
6. Balthazar, V., Vanacker, V., Girma, A., Poesen, J., \& Golla, S. J. G. (2013). Human impact on sediment fluxes within the Blue Nile and Atbara River basins. 180, 231-241.

7. BAYRAMIN, I., DENGIZ, O., BAŞKAN, O., \& PARLAK, M. (2003). Soil erosion risk assessment with ICONA model; case study: Beypazarı area. Turkish Journal of Agriculture Forestry, 27(2), 105-116.

8. Bewket, W., \& Teferi, E. (2009). Assessment of soil erosion hazard and prioritization for treatment at the watershed level: case study in the Chemoga watershed, Blue Nile basin, Ethiopia. Land Degradation Development, 20(6), 609-622.

9. Birru, Y. (2007). Land degradation and options for sustainable land management in the Lake Tana Basin (LTB), Amhara Region, Ethiopia. PhD Thesis, Centre for Development and Environment (CDE), Geographisches Institute, University Bern, Bern, Switzerland. Phd thesis.

10. , Sudhakar., \& Desai. (1999). Prioritisation of subwatersheds based on morphometric analysis of drainage basin: A remote sensing and GIS approach. Journal of the Indian society of remote sensing, 27(3), 155.

11. Brhane, G., \& Mekonen, K. (2009). Estimating soil loss using Universal Soil Loss Equation (USLE) for soil conservation planning at Medego watershed, Northern Ethiopia. Journal of American Science, 5(1), 58-69.

12. Chopra, R., Dhiman, R. D., \& Sharma, P. J. J. o. t. I. S. o. R. S. (2005). Morphometric analysis of sub-watersheds in Gurdaspur district, Punjab using remote sensing and GIS techniques. 33(4), 531.

13. Eweg HPA, v. L. R. (1996). The application of geographic information system at the Rehabilitation of degraded and degrading areas of Tigray, Ethiopia. Research Report, Wageningen Agricultural University, Wageningen. Msc thesis.

14. (1986). Ethiopian highlands reclamation study, Ethiopia. Final Report. Retrieved from Rome:

15. Farhan, Y., \& Nawaiseh, S. J. E. E. S. (2015). Spatial assessment of soil erosion risk using RUSLE and GIS techniques. 74(6), $4649-4669$.

16. Gessesse, B., Bewket, W., \& Bräuning, A. (2015a). Model-based characterization and monitoring of runoff and soil erosion in response to land use/land cover changes in the Modjo watershed, Ethiopia. Land Degradation Development, 26(7), 711-724.

17. Gessesse, B., Bewket, W., \& Bräuning, A. (2015b). Model-based characterization and monitoring of runoff and soil erosion in response to land use/land cover changes in the Modjo watershed, Ethiopia. Journal of Land degradation and development, 26(7), 711-724.

18. Gravelius, H. (1914). Morphometry of Drainage Bassins. In: Amsterdan: Elsevier.

19. Haregeweyn, N., Berhe, A., Tsunekawa, A., Tsubo, M., \& Meshesha, D. T. (2012). Integrated watershed management as an effective approach to curb land degradation: a case study of the Enabered watershed in northern Ethiopia. Environmental management, 50(6), 1219-1233.

20. Haregeweyn, N., Tsunekawa, A., Poesen, J., Tsubo, M., Meshesha, D. T., Fenta, A. A., . . Adgo, E. (2017). Comprehensive assessment of soil erosion risk for better land use planning in river basins: Case study of the Upper Blue Nile River. Sci Total Environ, 574, 95-108. doi:10.1016/j.scitotenv.2016.09.019

21. Horton, R. (1932). Drainage basin characteristics, American Geophysical. In: Union.

22. Hurni, H. (1983). Soil Erosion and Soil Formation in Agricultural Ecosystems: Ethiopia and Northern

23. Mountain Research and Development, 3(2), 131-142.

24. Hurni, H. (1985a). Erosion-productivity-conservation systems in Ethiopia.

25. Hurni, H. (1985b). Erosion-productivity-conservation systems in Ethiopia. Paper presented at the 4th international conference of soil conservation,3-7 November.

26. Hurni, H. (1986). Guidelines for development agents on soil conservation in Ethiopia.

27. Hurni, H. (1993). Land degredation, famine, and land resource scenarios in Ethiopia.

28. Kaltenrieder, J. (2007). Adaptation and validation of the Universal Soil Loss Equation (USLE) for the Ethiopian-Eritrean Highlands. Unpublished thesis.

29. Keno, B., \& Suryabhagavan, K. (2014). Multitemporal remote sensing of landscape dynamics and pattern change in Dire district, southern Ethiopia. Journal of Geomatics, 8(2).

30. Khadse, G. K., Vijay, R., \& Labhasetwar, P. K. (2015a). Prioritization of catchments based on soil erosion using remote sensing and GIS. Environmental Monitoring Assessment, 187(6), 333.

31. Khadse, G. K., Vijay, R., \& Labhasetwar, P. K. (2015b). Prioritization of catchments based on soil erosion using remote sensing and GIS. Journal of Environmental monitoring assessment, 187(6), 333.

32. Lal, R. (2001). Soil degradation by erosion. Journal of Land degradation and development, 12(6), 519-539.

33. Lin D, G. Y., Wu Y, Shi P, Yang H, Wang J. (2017). A conversion method to determine the regional vegetation cover factor from standard plots based on large sample theory and TM images: a case study in the eastern farming-pasture ecotone of northern China. Remote Sens 9:1035. https:// doi.org/10.3390/rs9101035

34. Markose, V. J., \& Jayappa, K. (2016). Soil loss estimation and prioritization of sub-watersheds of Kali River basin, Karnataka, India, using RUSLE and GIS. Environmental Monitoring Assessment, 188(4), 225.

35. Mengie Belayneh , T. Y. a. D. T. (2019). Potential soil erosion estimation and area prioritization for better conservation planning in Gumara watershed using RUSLE and GIS techniques. Environment and system research, 8(20). doi:10.1186/s40068-019-0149-x

36. Moges, D. M., \& Bhat, H. G. J. E. e. s. (2017). Integration of geospatial technologies with RUSLE for analysis of land use/cover change impact on soil erosion: case study in Rib watershed, north-western highland Ethiopia. 76(22), 765.

37. Monsieurs, E., Dessie, M., Adgo, E., Poesen, J., Deckers, J., Verhoest, N., . . development. (2015). Seasonal surface drainage of sloping farmland: a review of its hydrogeomorphic impacts. 26(1), 35-44. 
38. Patel, D. P., \& Dholakia, M. B. (2010). Feasible structural and non-structural measures to minimize effect of flood in Lower Tapi Basin. WSEAS Trans Fluid Mech, 3, 104-121.

39. Patel, D. P., Dholakia, M. B., Naresh, N., \& Srivastava, P. K. (2012). Water harvesting structure positioning by using geo-visualization concept and prioritization of mini-watersheds through morphometric analysis in the Lower Tapi Basin. Journal of the Indian Society of Remote Sensing, 40(2), 299312.

40. Prasad, R., Mondal, N., Banerjee, P., Nandakumar, M., \& Singh, V. (2008). Deciphering potential groundwater zone in hard rock through the application of GIS. Environmental geology, 55(3), 467-475.

41. Prasannakumar, V., Vijith, H., Abinod, S., \& Geetha, N. (2012). Estimation of soil erosion risk within a small mountainous sub-watershed in Kerala, India, using Revised Universal Soil Loss Equation (RUSLE) and geo-information technology. Journal of Geoscience Frontiers, 3(2), $209-215$.

42. Ratnam, K. N., Srivastava, Y., Rao, V. V., Amminedu, E., \& Murthy, K. (2005). Check dam positioning by prioritization of micro-watersheds using SYI model and morphometric analysis-remote sensing and GIS perspective. Journal of the Indian Society of Remote Sensing, 33(1), 25.

43. Renard, K. G. (1997). Predicting soil erosion by water: a guide to conservation planning with the Revised Universal Soil Loss Equation (RUSLE): United States Government Printing.

44. Renard KG, F. G., Weesies GA, McCool DK, Yoder DC. (1997). Predicting soil erosion by water: a guide to conservation planning with the Revised Universal Soil Loss Equation (RUSLE). USDA agricultural handbook 703, pp 126-131: USDA agricultural handbook

45. Reusing, M., Schneider, T., \& Ammer, U. (2000). Modelling soil loss rates in the Ethiopian Highlands by integration of high resolution MOMS-02/D2-stereodata in a GIS. International Journal of remote sensing, 21(9), 1885-1896.

46. Schumm, S. A. (1956). Evolution of drainage systems and slopes in badlands at Perth Amboy, New Jersey. Geological society of America bulletin, 67(5), 597-646.

47. Shiferaw, A. (2011). Estimating soil loss rates for soil conservation planning in the Borena Woreda of South Wollo Highlands, Ethiopia. Journal of Sustainable Development in Africa, 13(3), 87-106.

48. Singh, S., \& Singh, M. (1997). Morphometric analysis of Kanhar river basin. National geographical Journal of india, 43(1), 31-43.

49. Sonneveld, B. (2002). Land under pressure: the impact of water erosion on food production in Ethiopia. Shaker Publishing.

50. Strahler, A. N. (1964). Part II. Quantitative geomorphology of drainage basins and channel networks. 4-39.

51. Tamene, L., Abegaz, A., Aynekulu, E., Woldearegay, K., \& Vlek, P. L. (2011). Estimating sediment yield risk of reservoirs in northern Ethiopia using expert knowledge and semi-quantitative approaches. Journal of Lakes and Reservoirs Research Management 16(4), 293-305.

52. Tebebu, T., Abiy, A., Zegeye, A., Dahlke, H., Easton, Z., Tilahun, S., . . Sciences, E. S. (2010). Surface and subsurface flow effect on permanent gully formation and upland erosion near Lake Tana in the northern highlands of Ethiopia. 14(11), 2207-2217.

53. TEFERI, W. B. A. E. (2009). ASSESSMENT OF SOIL EROSION HAZARD AND PRIORITIZATION FOR TREATMENT AT THE WATERSHED LEVEL: CASE STUDY IN THE CHEMOGA WATERSHED, BLUE NILE BASIN, ETHIOPIA. land degradation \& development, 20, 609-622. doi:10.1002/Idr.944 10.1002/Idr

54. Tripathi, M., Panda, R., \& Raghuwanshi, N. (2003). Identification and prioritisation of critical sub-watersheds for soil conservation management using the SWAT model. Journal of Biosystems Engineering, 85(3), 365-379.

55. Tully, Katherine Sullivan, Clare Weil, Ray Sanchez, \& Pedro. (2015). The state of soil degradation in Sub-Saharan Africa: Baselines, trajectories, and solutions. J Sustainability, 7(6), 6523-6552.

56. Uddin, K., Murthy, M. S., Wahid, S. M., \& Matin, M. A. (2016). Estimation of Soil Erosion Dynamics in the Koshi Basin Using GIS and Remote Sensing to Assess Priority Areas for Conservation. PLoS One, 11(3), e0150494. doi:10.1371/journal.pone.0150494

57. Vandam, M. (2013). Morphometric analysis and watershed prioritization:case study of kabani river basin. Indian Journal of Geo_marine science, 211-222. 58. Wischmeier, W. H., Johnson, C., Cross, B. J. J. o. s., \& conservation, w. (1971). Soil erodibility nomograph for farmland and construction sites.

59. Wischmeier, W. H., \& Smith, D. D. (1978). Predicting rainfall erosion losses-a guide to conservation planning.

60. Zhang, Y., Degroote, J., Wolter, C., \& Sugumaran, R. (2009). Integration of Modified Universal Soil Loss Equation (MUSLE) into a GIS framework to assess soil erosion risk. Land Degradation Development, 20(1), 84-91.

\section{Figures}




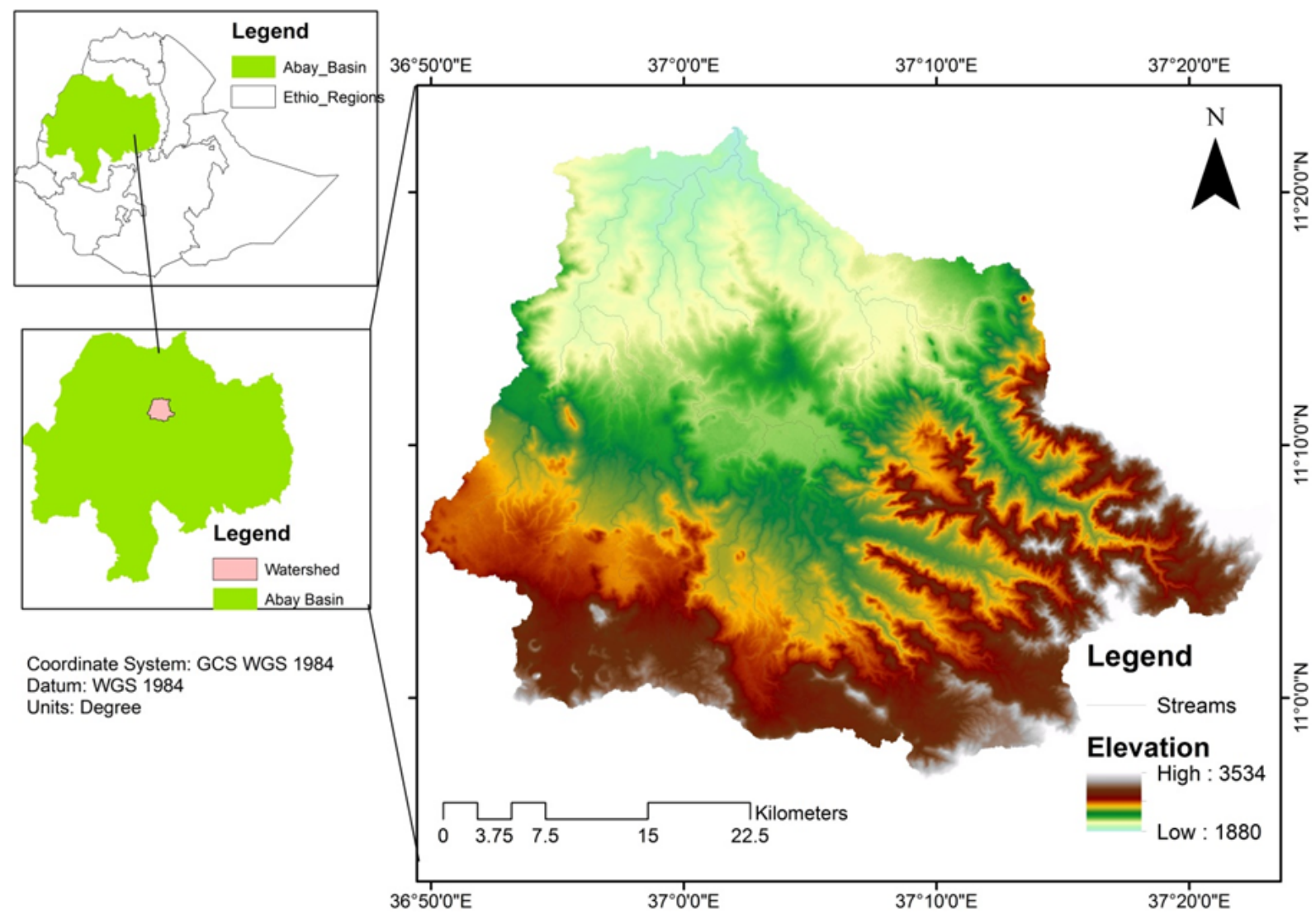

\section{Figure 1}

Study area location Note: The designations employed and the presentation of the material on this map do not imply the expression of any opinion whatsoever on the part of Research Square concerning the legal status of any country, territory, city or area or of its authorities, or concerning the delimitation of its frontiers or boundaries. This map has been provided by the authors. 


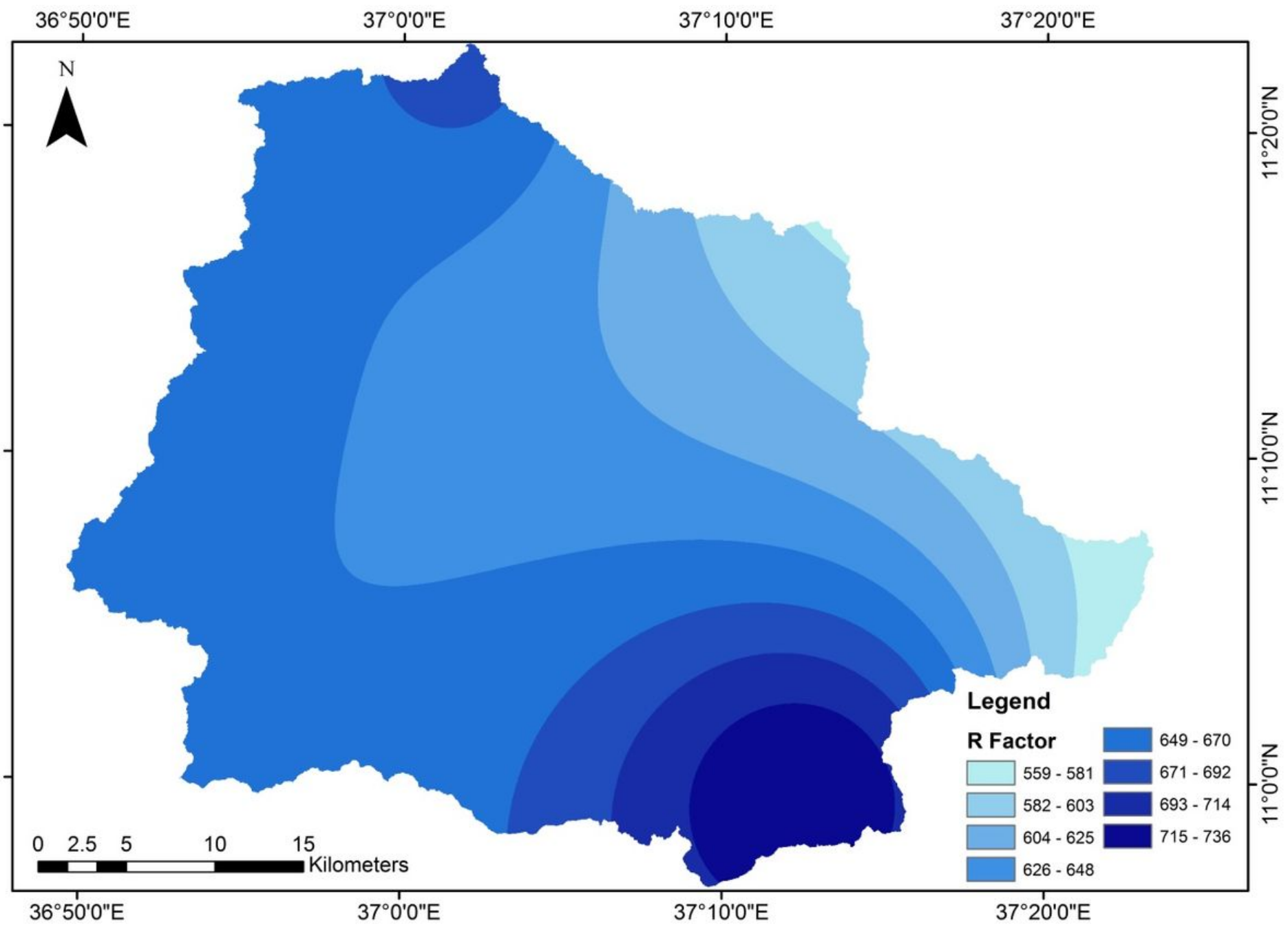

\section{Figure 2}

Rainfall erosivity ( $\mathrm{R}$ factor) in Gilgel Abay watershed. Note: The designations employed and the presentation of the material on this map do not imply the expression of any opinion whatsoever on the part of Research Square concerning the legal status of any country, territory, city or area or of its authorities, or concerning the delimitation of its frontiers or boundaries. This map has been provided by the authors. 


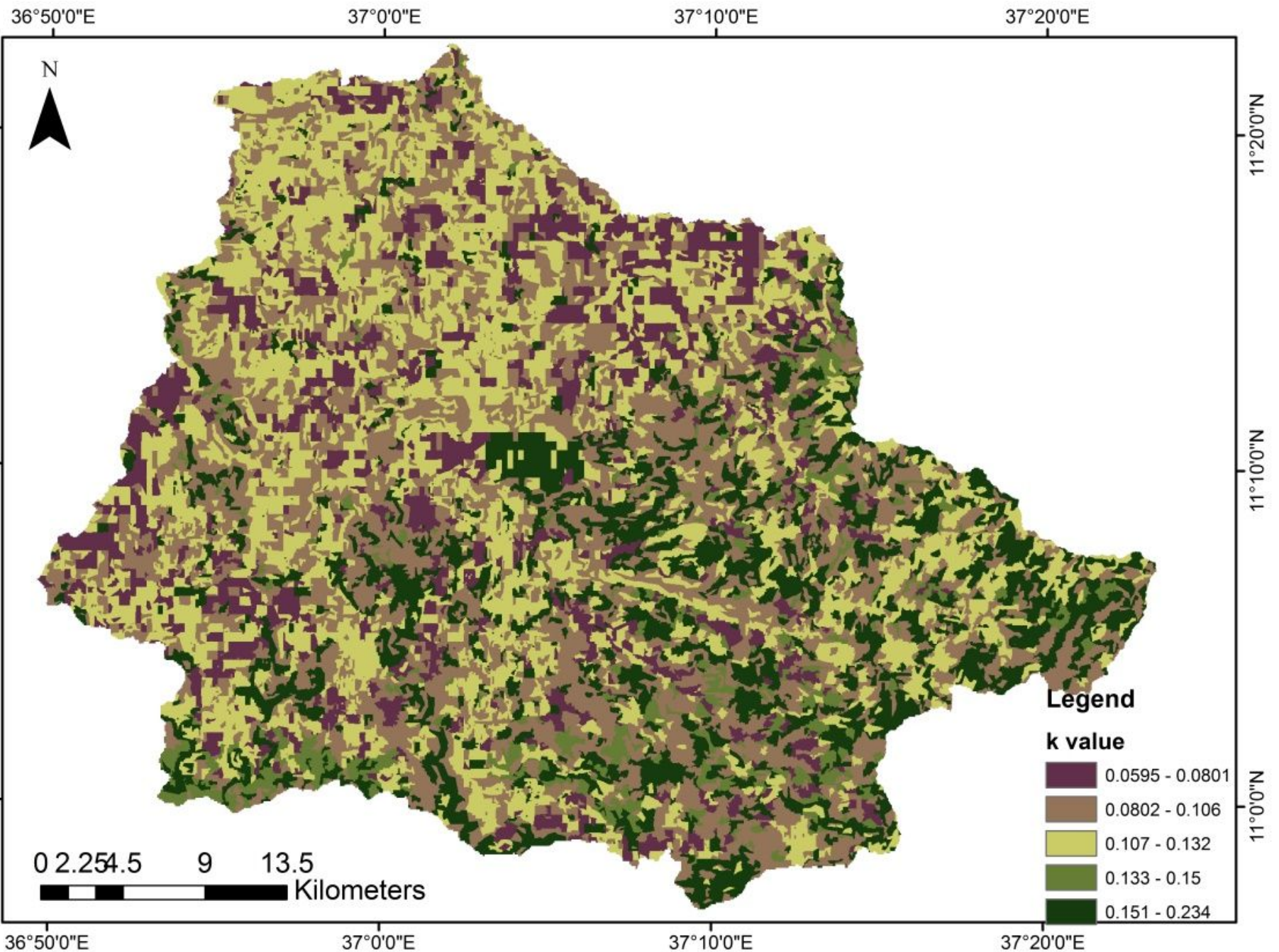

Figure 3

Soil Erodebility ( $\mathrm{K}$ factor) in Gilgel Abay watershed Note: The designations employed and the presentation of the material on this map do not imply the expression of any opinion whatsoever on the part of Research Square concerning the legal status of any country, territory, city or area or of its authorities, or concerning the delimitation of its frontiers or boundaries. This map has been provided by the authors. 


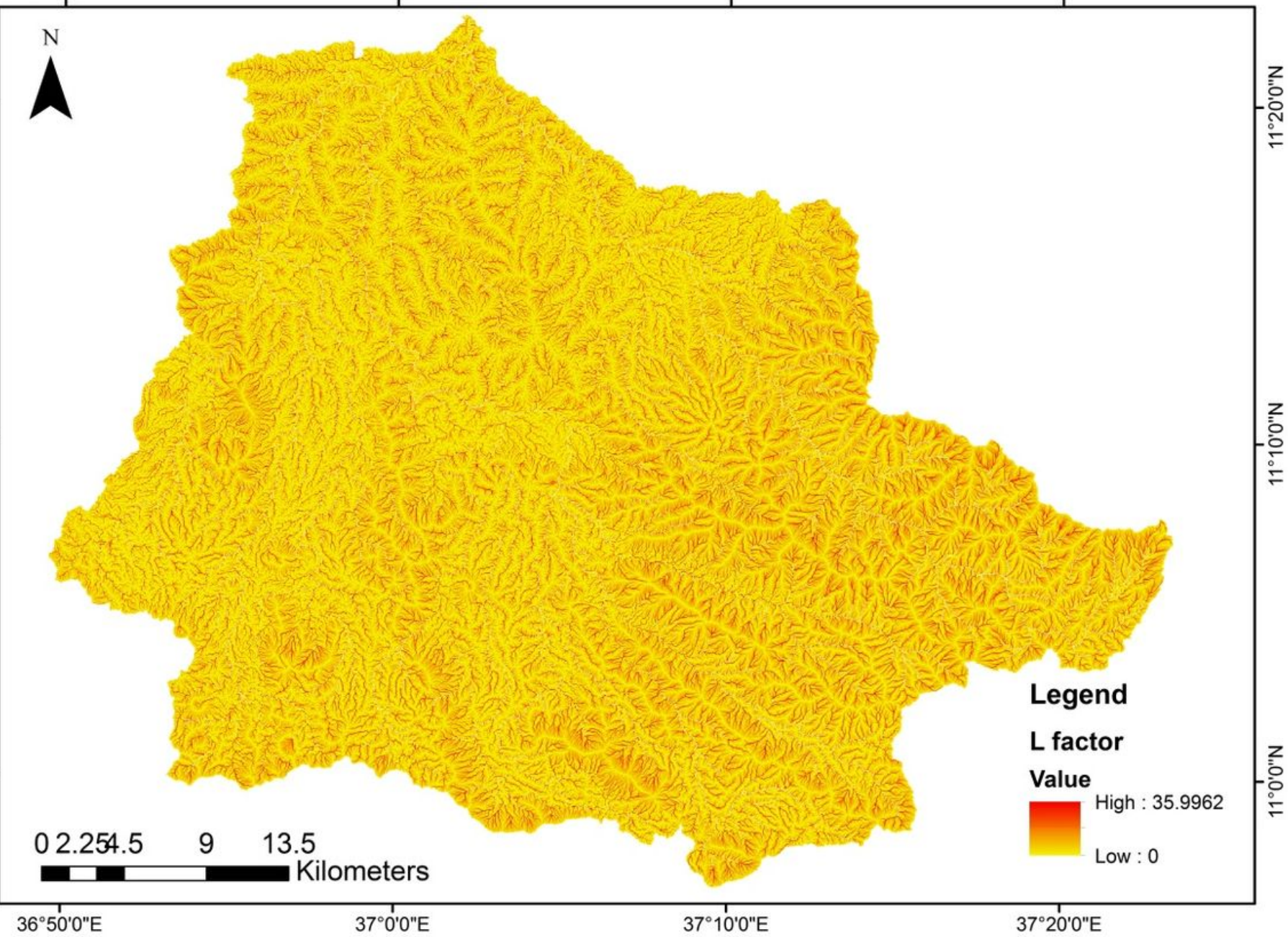

Figure 4

slope length ( $L$ factor) in Gilgel Abay watershed. Note: The designations employed and the presentation of the material on this map do not imply the expression of any opinion whatsoever on the part of Research Square concerning the legal status of any country, territory, city or area or of its authorities, or concerning the delimitation of its frontiers or boundaries. This map has been provided by the authors. 


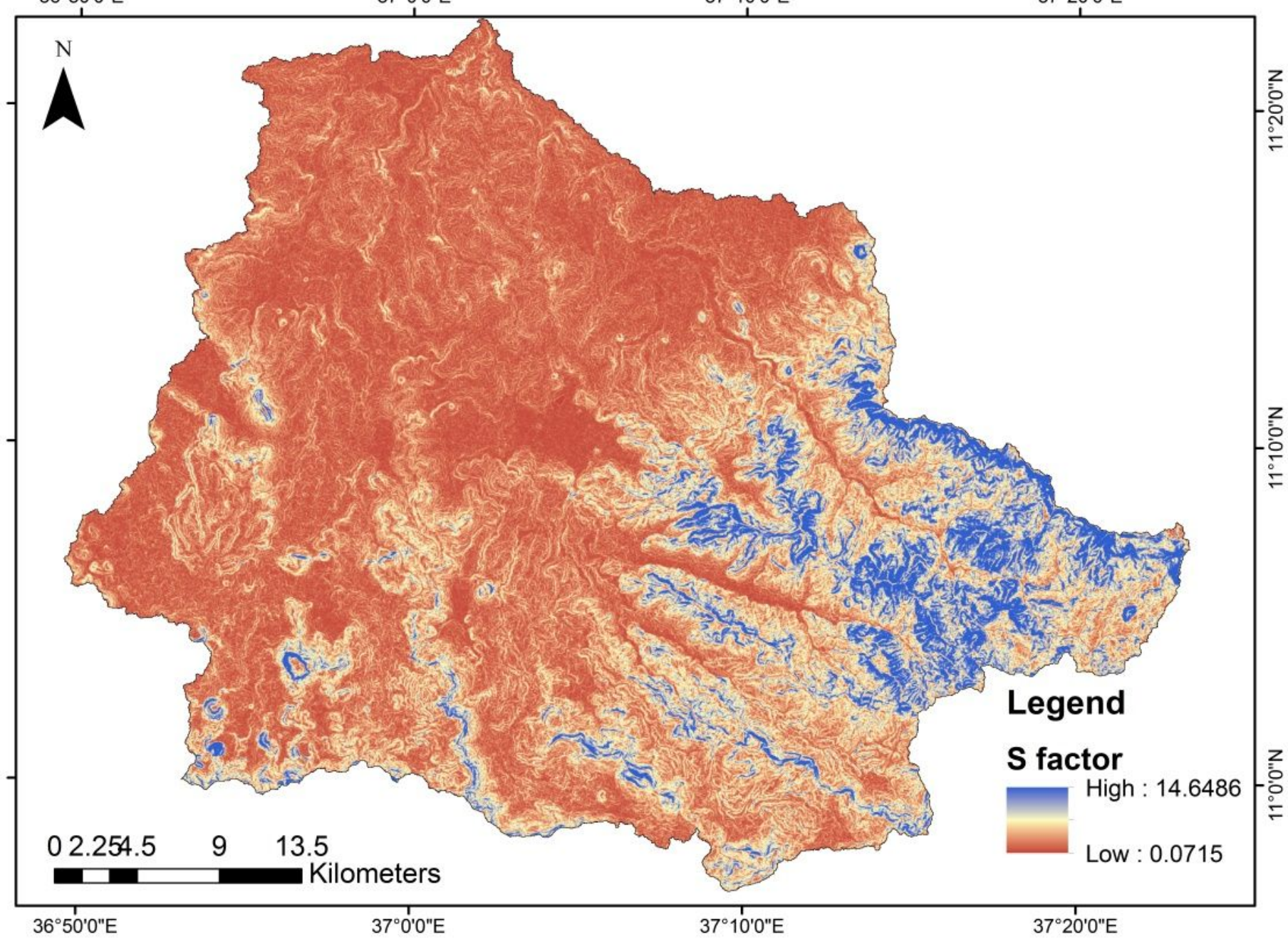

\section{Figure 5}

slope steepness (s factor) for Gilgel Abay watershed Note: The designations employed and the presentation of the material on this map do not imply the expression of any opinion whatsoever on the part of Research Square concerning the legal status of any country, territory, city or area or of its authorities, or concerning the delimitation of its frontiers or boundaries. This map has been provided by the authors. 


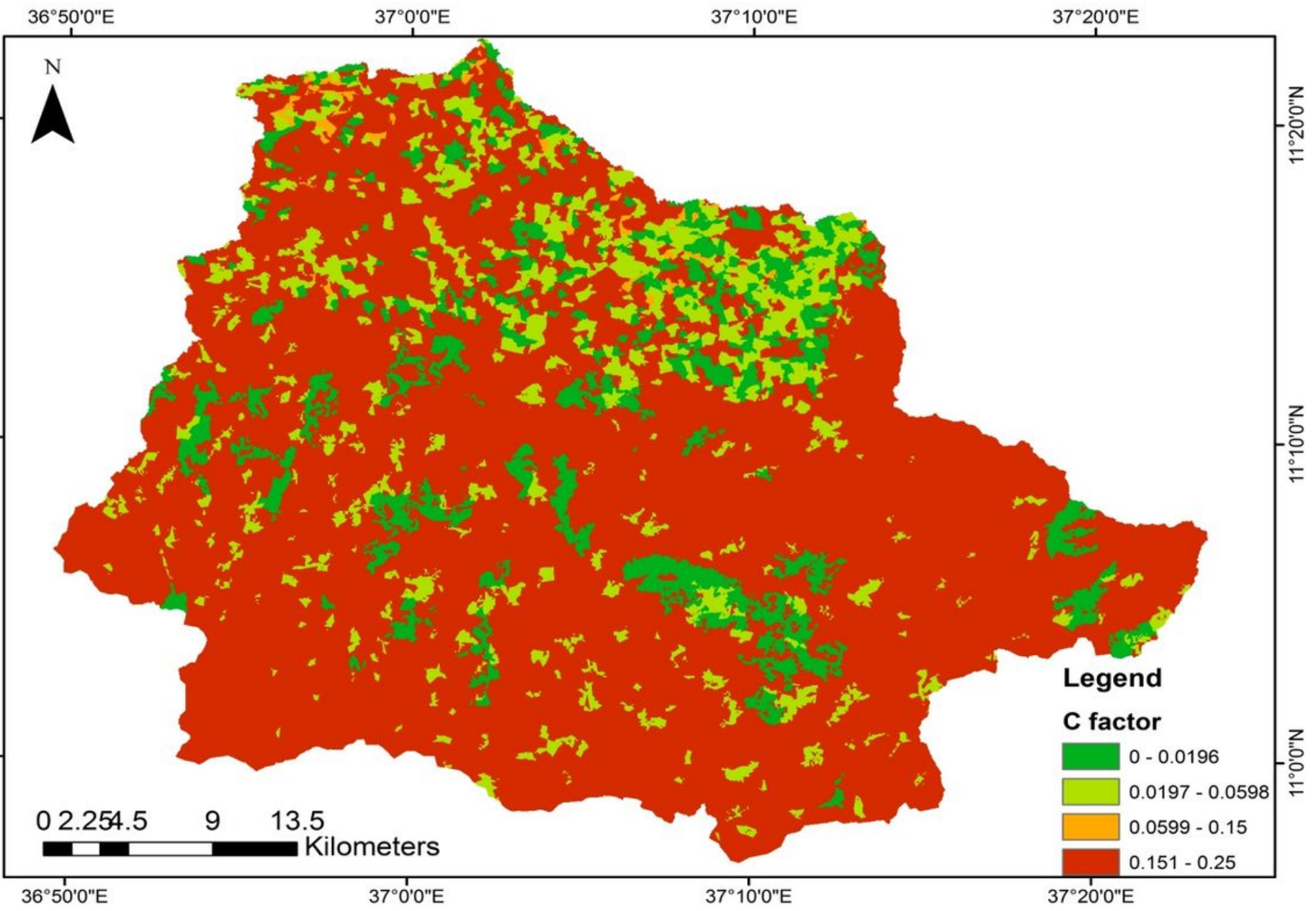

\section{Figure 6}

land cover management factor(C factor) Note: The designations employed and the presentation of the material on this map do not imply the expression of any opinion whatsoever on the part of Research Square concerning the legal status of any country, territory, city or area or of its authorities, or concerning the delimitation of its frontiers or boundaries. This map has been provided by the authors. 


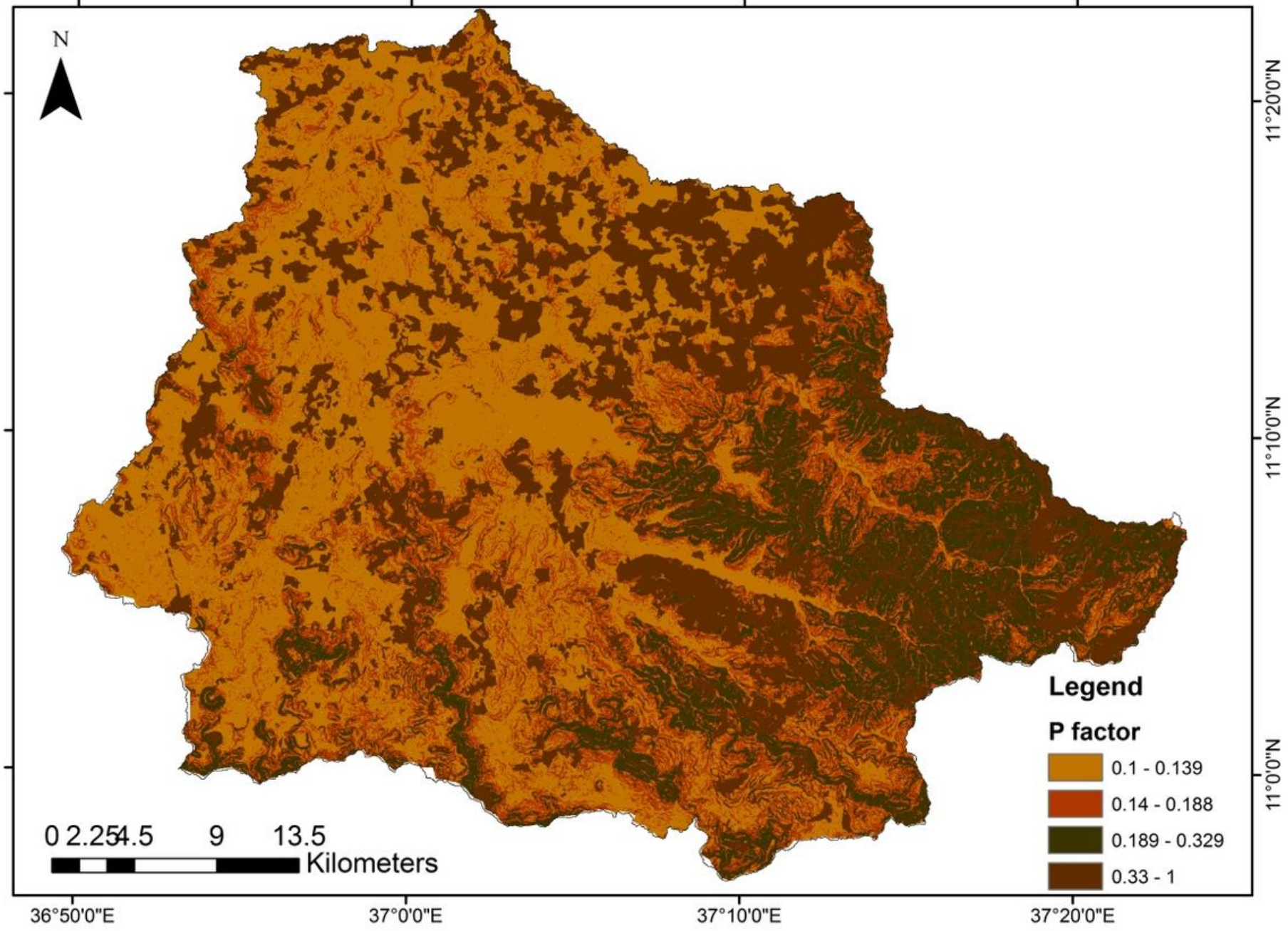

Figure 7

conservation practice factor ( $\mathrm{P}$ factor) Note: The designations employed and the presentation of the material on this map do not imply the expression of any opinion whatsoever on the part of Research Square concerning the legal status of any country, territory, city or area or of its authorities, or concerning the delimitation of its frontiers or boundaries. This map has been provided by the authors. 


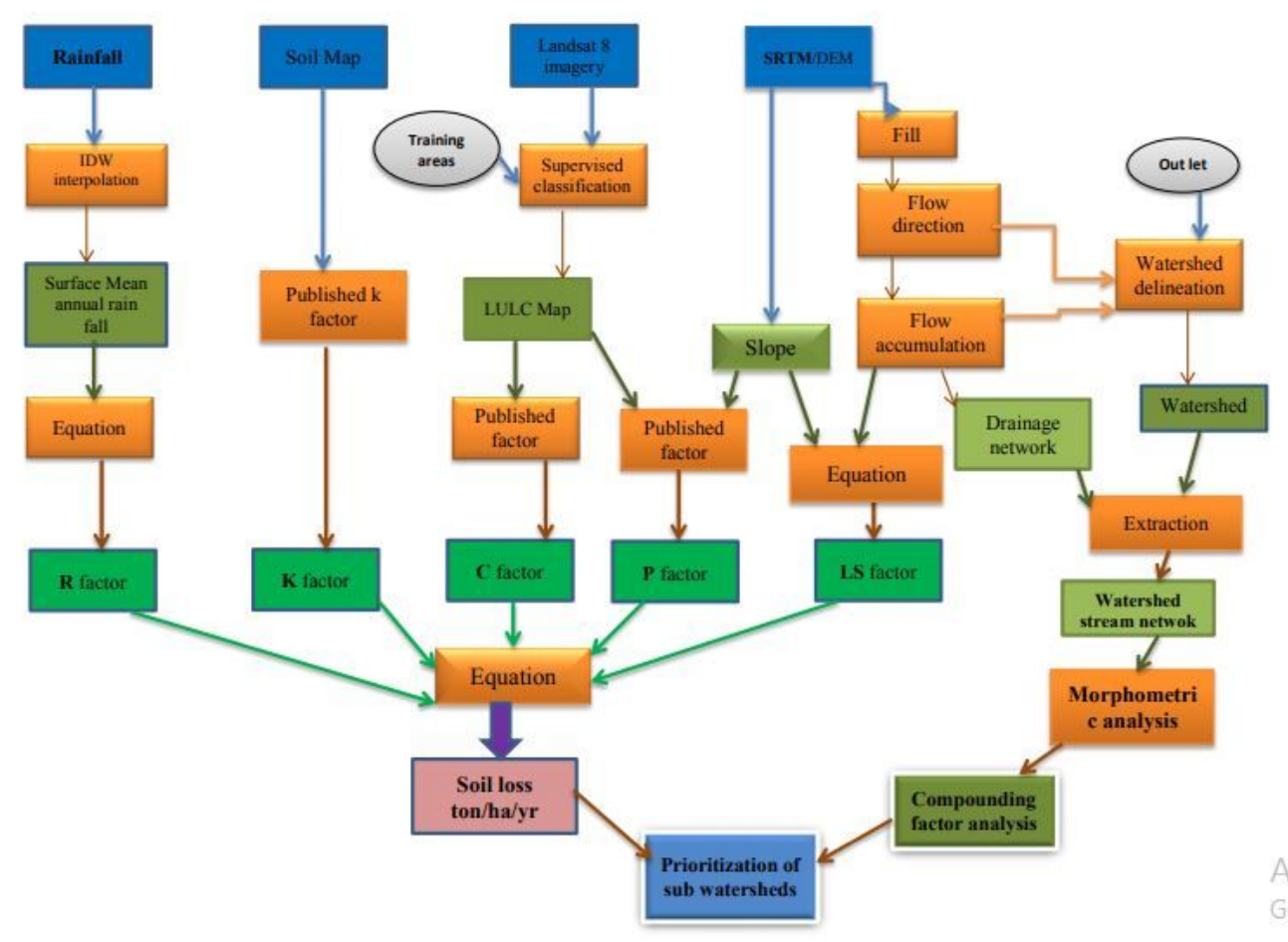

Figure 8

the overall workflow of the study.

$36^{\circ} 50^{\prime} 0^{\prime \prime} \mathrm{E}$ $37^{\circ} 0^{\prime} 0^{\prime \prime E}$ $37^{\circ} 10^{\prime} 0^{\prime \prime} \mathrm{E}$ $37^{\circ} 20^{\prime} 0^{\prime \prime} \mathrm{E}$

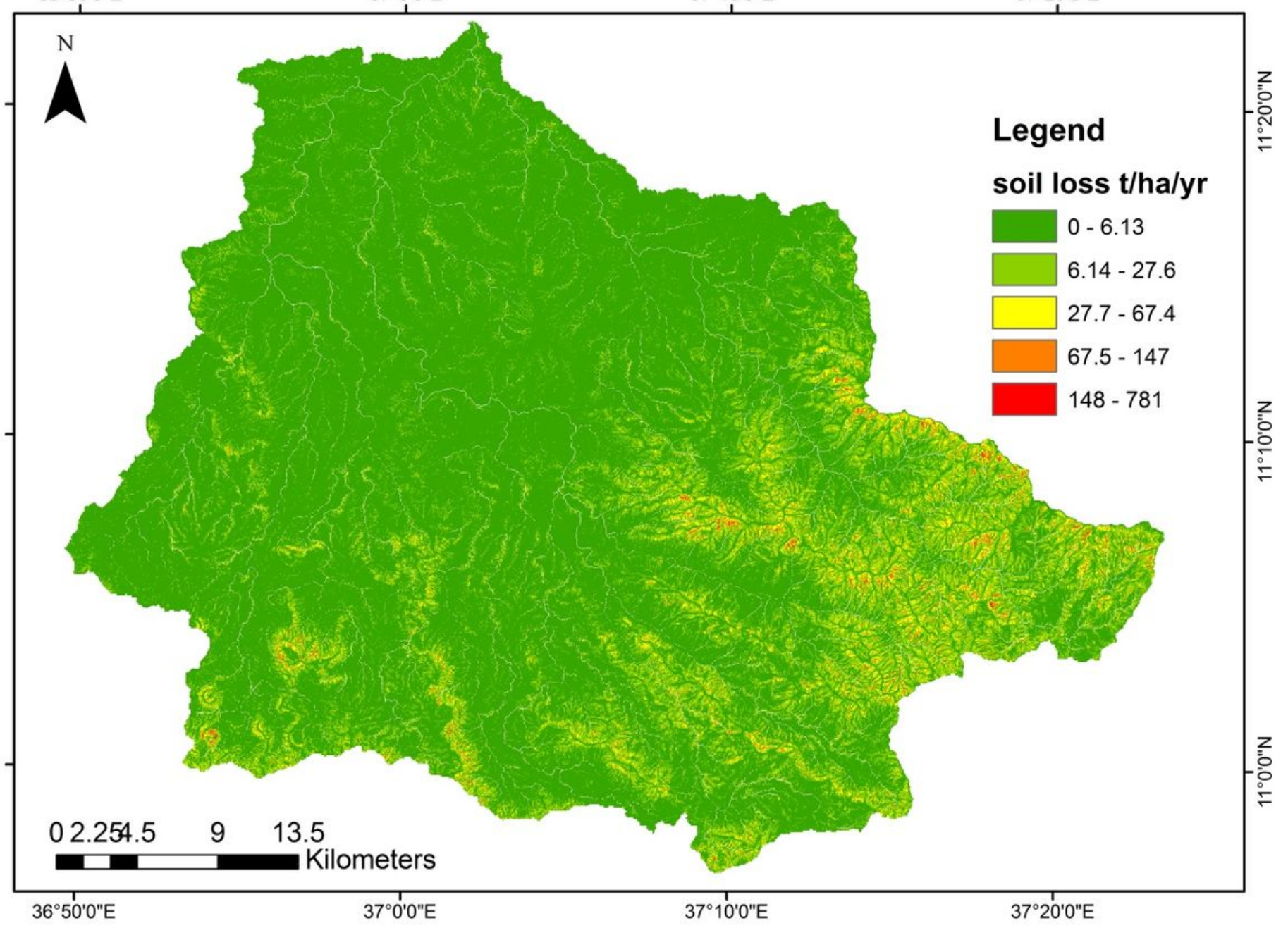




\section{Figure 9}

Annual soil loss rates in Gilgel Abay watershed Note: The designations employed and the presentation of the material on this map do not imply the expression of any opinion whatsoever on the part of Research Square concerning the legal status of any country, territory, city or area or of its authorities, or concerning the delimitation of its frontiers or boundaries. This map has been provided by the authors.

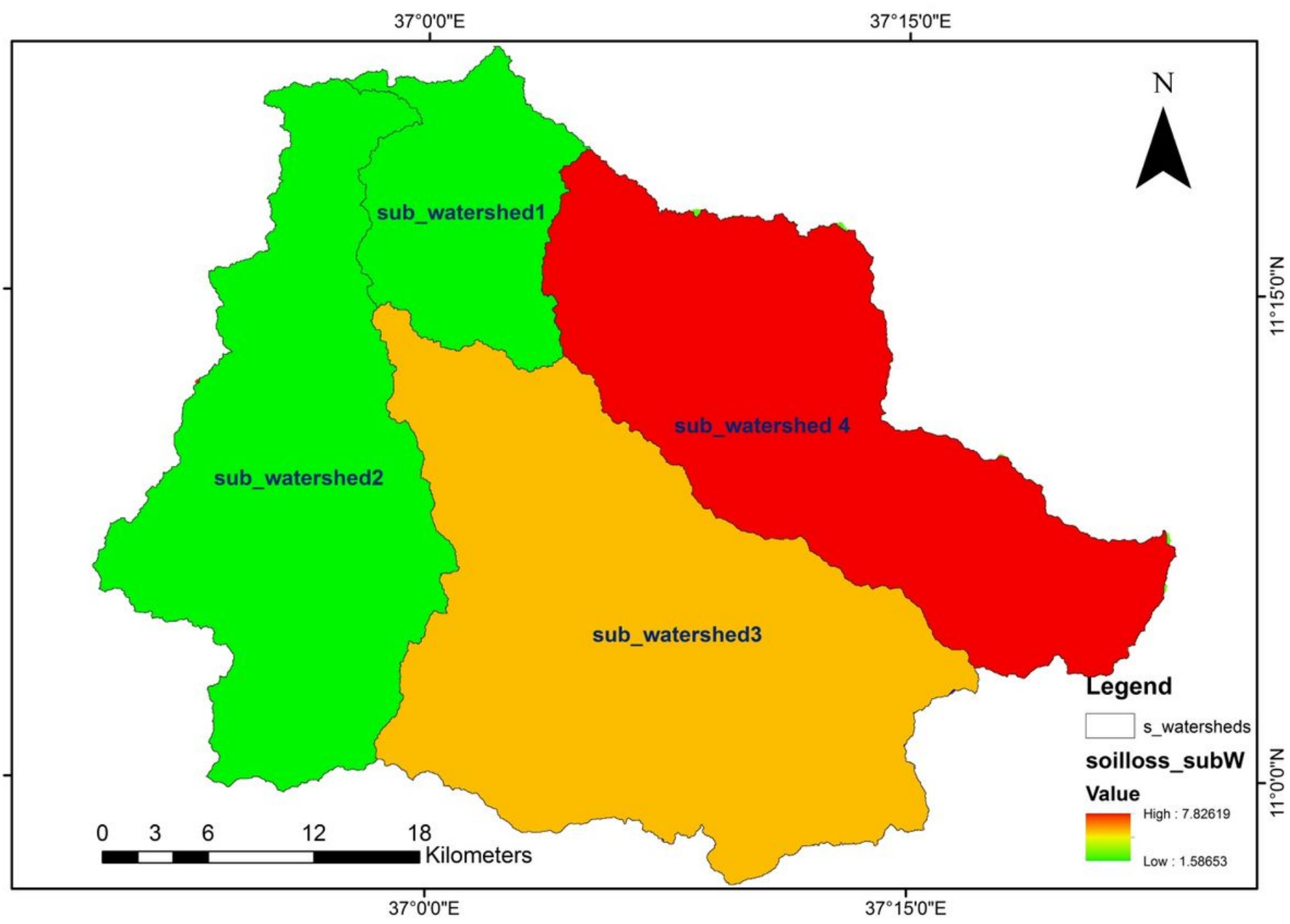

\section{Figure 10}

Soil erosion rate in the sub-watersheds. Note: The designations employed and the presentation of the material on this map do not imply the expression of any opinion whatsoever on the part of Research Square concerning the legal status of any country, territory, city or area or of its authorities, or concerning the delimitation of its frontiers or boundaries. This map has been provided by the authors. 